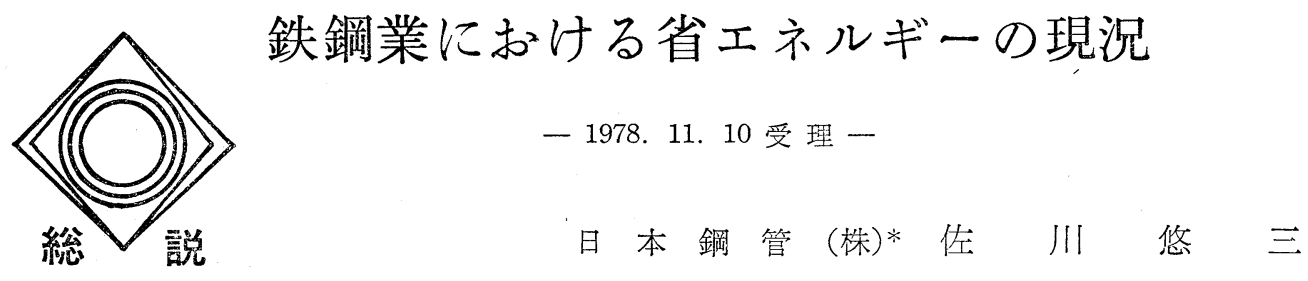

\section{1. あえがき}

鉄鋼業界にとって昭和 48 年の石油危機に引き続く世 界的不況の影響は戦しく, 中長期生産計画の見透しが 一挙に 5 年分後退したとさえいわれている。先れだけ に各企業は山らゆる合理化施策の中に将来に向けての 活路を見出すべく㲘命の努力をつづけているのが現状 とい光る。

昭和 49 年度当時までの省エネルギー詨策はぞるらか といえば，エネルギー価格高騰に䞑する応急対処的な 性格が強かったとい方る。しかし，銑鉄から最終製品 までを生産する銑鋼一貫製鉄所に预いても，そのシン ボルである高炉の休止が相次ぎ, 低成長下に晾斿る省 エネルギー対策を合理化の中にどのように位置づける かを模索する段階に立ら至った。

そして，このような様相の変化は，過去の高度成長 時代の技術力の蓄積の延長線上で解決されつつ岁ると はいえ, 細部にわたってはより以上に発想の䎐換が要 求され，また，新しいエネルギー技術の開発が必要と なっている。

昭和49年度ごろまでのエネルギー高価格に対処する ための諸対策とその戦略目標が，円高ドル安の国際経 済の中で，さらに鉄鋼業が活路を見出すための第 2 段 階の省エネルギー戦略目標の確立に向けて, より広い 視野からのトータルエネルギーコストミニマムを指向 し続けていることは, ひとつの重要な転換期を迎えた とみることができる。

従来とも，鉄鋼業に乱少省エネルギー対策につい ては，各種の報文で紹介されているが，このような意 味で，本稿では，銑鋼一貫製鉄所の現状を概括して， 参考に供することとしたい。

\section{2. 銑鋼一貫製鉄所エネルギー消費の概括}

\section{1 エネルギー消費の特徵}

わが国エネルギー消費の約 17〜18\% が鉄鋼業で消 費されるといわれている。一般に，鉄鋼業はエネルギ 一多消費産業とよばれているが，その約 86\%を占め

*鉄鋼技術部エネルギー管理室 東京都千代田区丸の 内1-1-2
る一貫製鉄所のエネルギー消費には，幾多の特徴があ る。

その第 1 は，消費エネルギーの構成内訳が，石炭系 エネルギー主流型であることである。図1は，当社福

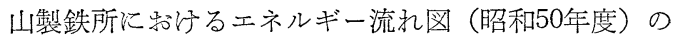
例であるが，購入エネルギーの約 75\% を石炭系が占 めている。全銑鋼一貫製鉄所の集計でみると, ニーク スを全量購大している製鉄所があることなどから，そ の構成此は若干異なるが，購入エネルギーとして，石 炭およびュークスが 66\%, 電力 14\%, 石油系 13\%, その他（酸素・LNG など）7\% となっている。

第 2 は，この主流を占める石炭揢よびュークスと石

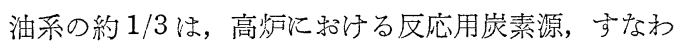
ち銑鉄製造からみれば原料用として消費されるが，こ の際多量の高炉ガス (B ガス)，コークス炉ガス (C ガス)、タールなぞを副生し，いわゆる加熱用燃料， 発電用燃料として消費されている。るた，製鋼用䎐炉 に䋇いては，熔銑と吹煉用酸素の反応により CO に 富む転炉ガス（LD ガス）も副生する。このように， 多量の副生エネルギーを産出することは観点をかえる ならば一種のエネルギー変換産業的性格を持つことに なる。これら副生エネルギーは一貫製鉄所が必要とす るエネルギー（購入一副生）の約 53\%にも達してい る。

このような，エネルギー消費の特徵は，一貫製鉄所 全体の省エネルギーを考光る場合に非常に重要な点で あり，各㣫の対策が全体のエネルギーバランスに対す る寄与度と，それによるエネルギーバランスそのるの の整合性を確かめながら推進すべきことに結びついて いると考光られている。

\section{2 エネルギー消費の現況}

一貫製鉄所は，立地条件その他により画一的ではな い。它と觉ば，先にも述べたと和りコークス炉を持っ か, コークスを購入するか, 自家発電か共同火力か, 酸素発生設備有無などエネルギー囷の䚍設備のあり方 によってニネルギー運用は異なってくる。

ま六, 生産設備個々の設備能力, 生産品種の相異な 


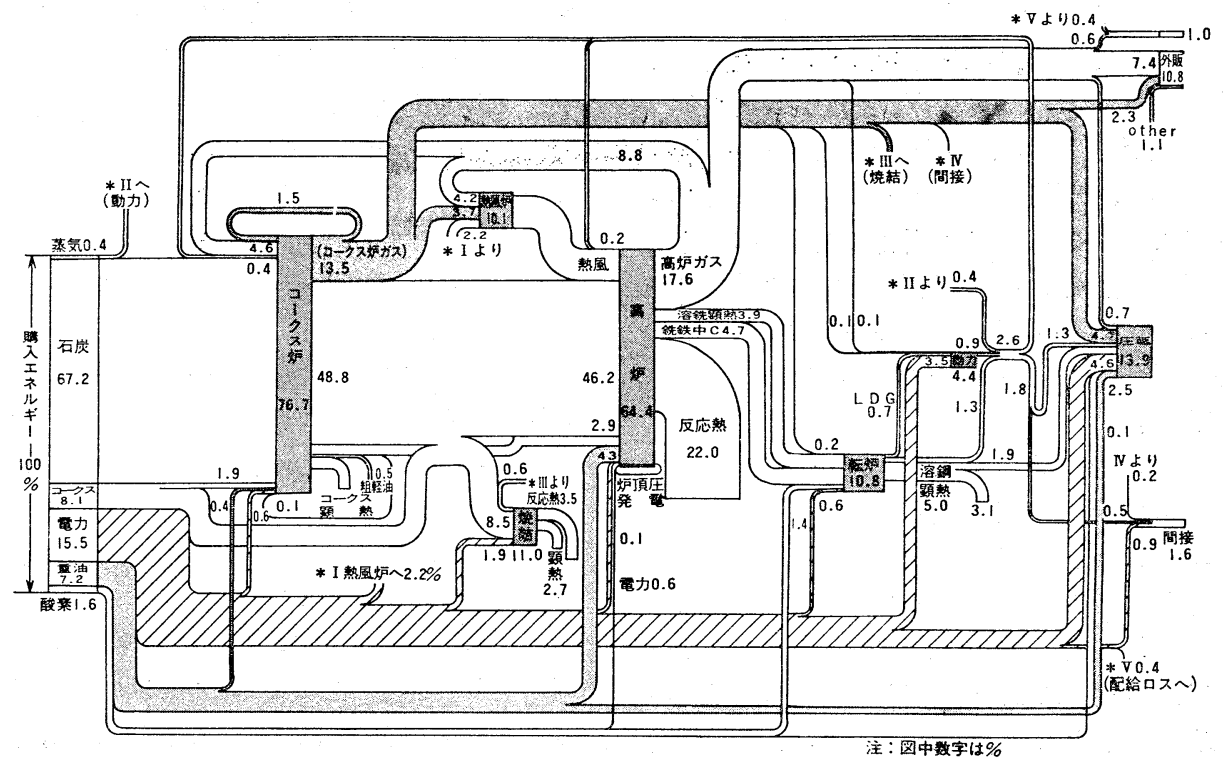

図 1 一貫製鉄所エネルギー流れの例（NKK 福山 S.50年度）

ぞ，直接エネルギー消費量に係る条件すある。さらに 環境保全の見地から選択すべき燃料の制約など一様で はない。したがって，エネルギー消費を各製鉄所を横 そ並べたデータのみで論ずることは，あをり意味のな いことになる。ここでは，わが国の一貫製鉄所全体と しての傾向をのべることとしたい。

図 2 は昭和 47 年度から昭和 51 年度にいたる粗鋼生産 量, 熔銑比（転炉などに和ける熔銑と屋鉄の装入比の 熔銑％）拉よび粗鋼 $\mathrm{t}$ あたりのエネルギー原単位の 傾向を示したものである。昭和50年度を境に顕著なこ とは，粗鋼生産量の激減，熔銑比の急上昇である。一 般に, 減産下では原料需給や高灯操業の維持岕るいは 屑鉄の市況などの要素が複雑にからむので, 結果とし て，熔銑比が上昇する。このことは，後でのべるよう に一貫製鉄所のエネルギーの大部分が銧鉄生産段階で 消費されるので，通常エネルギー評価をしない屑鉄に 置き代った分だけ粗鋼 $\mathrm{t}$ あたりのエネルギー原単位は 高くなる。その值は熔銑比 $1 \%$ 增に対し粗鋼 $\mathrm{t}$ あた り約 $3.5 \times 4.5$ 万 kcal 増といわれている。るちろん エネルギー原単位を左右する要因はこれだけではない が，熔鉄比の影響は非常に大きな比重を占める。

しかし，現状でのエネルギー原単位は，図2 亿示さ れると扮り，石油危機時の水準に対してほ核横ばいの 推移でありマクロ的には省エネルギー努力が証明され た実績值といえよう。ちなみに，生産構造を昭和48年 度なみに補正した場合の昭和51年度の一貫製鉄所粗鋼

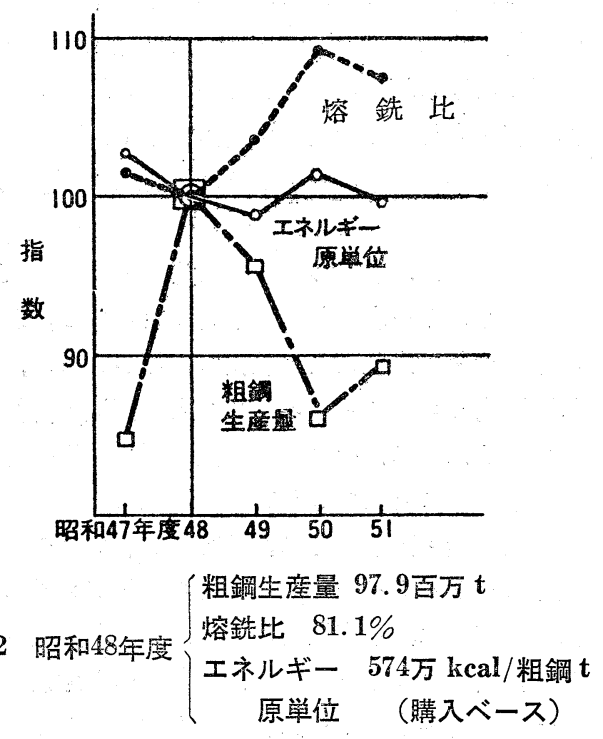

$\mathrm{t}$ あたりエネルギー原単位は昭和 48 年度実績比約 $5 \%$ 前後の節減淿相当するものと推測される。

鉄鋼一貫製鉄所の昭和51年度の主な実績值を整理す るとつぎのようになる。

銑鉄生産量 $\quad 87,600 \times 10^{3} \mathrm{t}$

粗鋼生産量 $\quad 87,200 \times 10^{3} \mathrm{t}$

購入エネルギー量 609兆 kcal

総使用エネルギー量*1 866兆 $\mathrm{kcal}$

コークスー次補正総エネルギー量*2 1,138 兆 $\mathrm{kcal}$ 


\section{総使用エネルギー量*3 563兆kcal}

すなわち，総使用エネルギー量は一貫製鉄所全体で の消費熱量換算, コークスー次補正総使用エネルギー 量は一貫製鉄所総使用エネルギーを石炭ベースに換算 したものであり，純使用エネルギーは一貫製鉄所がエ ネルギーそのものの費用として外部に支払らべき熱量 換算量で㐫る。蛇足であるが検討の目的によって使い わけているが，究極的に省エネルギー目標を策定する 際は純使用エネルギー量をべースにしているのが通常 の場合である。

\section{3. 省エネルギー対策の現況}

\section{1 省エネルギー対策の概況}

最初にのベたように，現状では省エネルギー対策も また不況脱出のための合理化の一環として重視されて いる。石油危機直後の高度成長期に叔けるエネルギー 使用技術上の盲点，たとえば管理強化による操業基準 の見直し的な段階をほぼ卒業した現在では，より高度 な技術開発とその結集した成果の具体適用が図られて いる。しかし，省エネルギー対策も経済性を無視して 走ることは許されないし，まして不況下であるだけに 一般的には限界として $2 \sim 3$ 年での採算性のあるるの が取りあげられているようである。これとても既存技 術の組み合わせで達成可能なものは注洼出つくし， さらに效果的なものを追求しているのが現段階であ る。

基本的には，生産プロセスの省略や改善によるも の，エネルギー利用効率の改善によるもの，拉よび排 エネルギーの回収などの技術に分類されるが，一貫製 鉄所特有のエネルギーバランスとの関連で評価づけら れているだけに，それぞれの技術項目を画一的にラン クづけすることはできない。

連続鋳造・直送圧延に代表される省プロセス型の対 策やヒートパターンの改善による各熱プロセスの効率 向上の技術は，生産技術の結集によって達成されるも ので，省エネルギー対策のための主流と考光られる。 一方，排エネルギー回収に関連するものは，一見独 立した技術とみられがちであるが，生産プロセスの変 化に対応した回収対象エネルギー源の質・量の動向や 設備投資額・設置スペースならびに全体のエネルギー バランスーの影響など,むしろ現実には近い将来に持

*1 総使用 エネルギー 量 $=($ 購入十副生 $)-($ 外販十損 失)

*2 コークスー次補正総使用エネルギー量=購入コー クス製造用エネルギーを加味し *1 を補正

*3 純使用エネルギー量 $=$ 購入一外販
ら込されるべき課題の残された分野である。

このようにみてくると，現況での省エネルギー対策 は，まず製鉄所内での省エネルギーの限界を見定める ことと，その段階での未利用エネルギー（製鉄所レベ ルでの余剩）の多目的利用の端緒に足を踏み入れ挑戦 しつつあるといえよう。

\section{2 各分野での省エネルギー対策例}

\section{2 .1 製銧部門}

製鉄部門は高炉を中心に，一貫製鉄所総使用エネル ギー量の約 73\% を消費する。と同時に B ガス，Cガ ス,タールなどの副生エネルギーを他部門に供給する 役割を果している。

高炉に跨けるエネルギー使用の尺度は一般に燃料比 で表わされるが図 3 亿みられるように逐年低下してい る。これは，表 1 亿代表される製銑部門省エネルギー 対策の操業面の改善に負らところが大きい。世界的に みても非常に高度な技術水準にある。ただ，高炉燃料 比の低減はエネルギー的にみて付带部門での増エネル ギーや副生ガスなぞの減少を十分にカバーするもので なければ意味をなさないことは当然であり，付带部門 でも表1にみられるよらな対策が進められている。

最近に和汀るこの部門での顕著な動向は, 各設備が 大型であるだけに，操業や設備面での改善が率よりも 絶対值で大きい効果をもたらすことと同意義に排エネ ルギー回収に努力が重衫られていことである。

高炬灯頂圧発電 (TRT) は当初ソ連やフランスか ら導入された技術ではあるが，現在では国産技術とし て消化されて抢り，業界としても一般的排熱回収面 で経済性のある技術と評価されている。図4 はと概 念図の一例であるが，たとえばガスヒーターの効率改

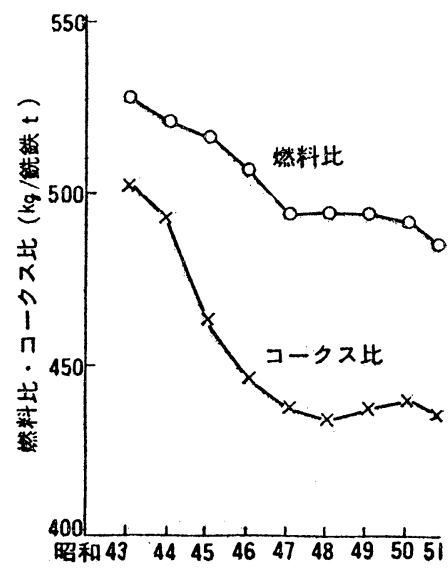

図 3 高炬燃料比 
表 1 製鉄部門省エネルギー対策例

\begin{tabular}{|c|c|c|}
\hline 高炉操業改善 & 付帯設備改善 & 排熱回収利用 \\
\hline 高温送風 & \multirow{4}{*}{\begin{tabular}{|l|} 
熱風炉 \\
○スタッカードパラ \\
レル送風 \\
○燃焼管理 \\
○切り替え方法改善
\end{tabular}} & 高炬炉頂圧発電 \\
\hline 高圧操業 & & ユークス炉乾式 \\
\hline \multirow{3}{*}{$\begin{array}{l}\text { 複合送風 } \\
\text { ○重油吹込及 } \\
\text { ○酸素富化 } \\
\text { ○脱湿送風 }\end{array}$} & & \\
\hline & & 熱風炉排熱利用 \\
\hline & $\begin{array}{l}\text { ユークス炉 } \\
\text { ○計算機制御 }\end{array}$ & $\begin{array}{l}\text { 焼結クーラ排熱 } \\
\text { 回収 }\end{array}$ \\
\hline \multirow{3}{*}{$\begin{array}{l}\text { 前処理強化 } \\
\text { ○焼結ペレット } \\
\text { 比の向上 } \\
\text { ○鉱石の整粒 } \\
\text { 還元ペレット } \\
\end{array}$} & \multirow{3}{*}{\begin{tabular}{|l} 
焼 \\
結 \\
点火炉燃焼管理 \\
O保熱炉の活用 \\
○保全強化 \\
\end{tabular}} & \multirow{8}{*}{$\begin{array}{l}\text { 排煙脱硫装置排 } \\
\text { 熱利用 } \\
ヘ ゚ レ ッ ト \text { 排熱利 } \\
\text { 用 }\end{array}$} \\
\hline & & \\
\hline & & \\
\hline $\begin{array}{l}\text { その他 } \\
\text { ○スラグ比低下 }\end{array}$ & \multirow{5}{*}{$\begin{array}{l}\text { ペレット } \\
\text { O総合管理の強化 }\end{array}$} & \\
\hline ○熔銑 S \% 低下 & & \\
\hline $\begin{array}{c}\text { ○ュークス中灰 } \\
\text { 分の低下 }\end{array}$ & & \\
\hline ○副原料装入 & & \\
\hline $\begin{array}{l}\text { ○装入物分布の } \\
\text { 改善 }\end{array}$ & & \\
\hline
\end{tabular}

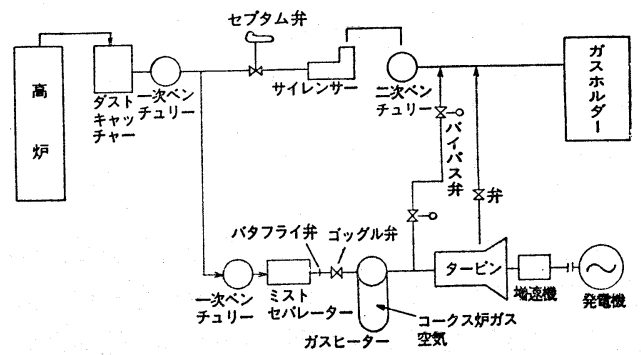

図 4 高炉炉頂圧発電概念図（ソ邀式）の一例

善によって逐時発電効率が上昇して和り，各一貫製鉄 所とも条件をみて設置されつつある。出力は高炉の大 きさによっても異なるが 8,000～15,000kWh（定格） 級のものが稼動あるいは建設されている。高炉炉頂ガ スの圧力ポテンシャルを利用した極めて有力な省エネ ルギー対策である。

また，高炉の脱湿送風は，とくに湿度の高いわが国 の立地条件から誕生した技術であるが，空気中湿分を $5 \mathrm{~g} / \mathrm{Nm}^{3}$ 程度に安定させる。湿分 $10 \mathrm{~g} / \mathrm{Nm}^{3}$ の脱湿 はコークス比 $8 \mathrm{~kg}$ の低減と評価されて扣り，10指 に余る方式が開発され実用に供されている。

図 5 は焼結成品クーラー排熱回収の概念図である。 赤熱焼結鉱は成品クーラーで空冷されるがその際の

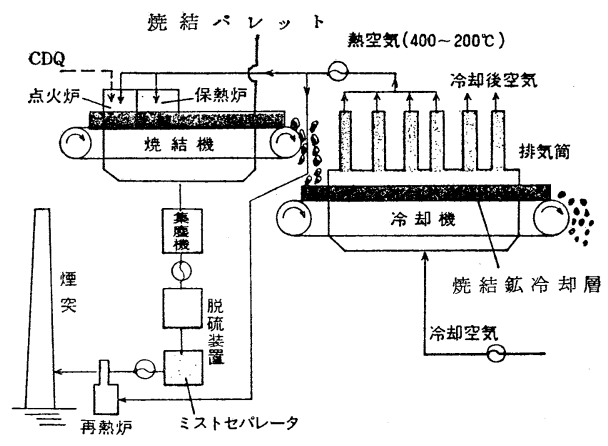

図 5 焼結成品クーラー排熱回収概念図の一例

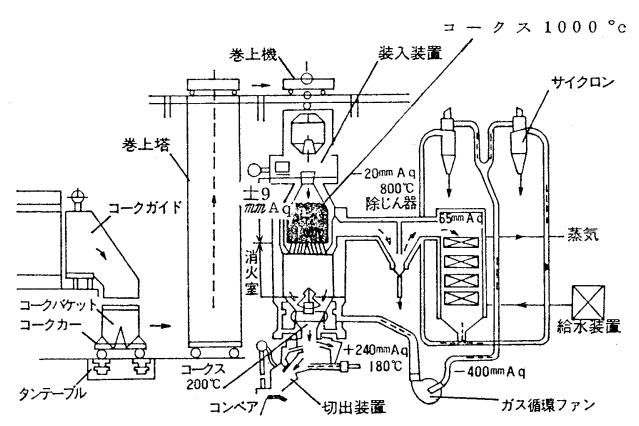

図 6 コークス乾式消火装置概念図

$50 \sim 60$ 万 $\mathrm{Nm}^{3} / \mathrm{hr}$ の熱空気 $400 \sim 200^{\circ} \mathrm{C}$ から熱回収を 行ない焼結機の保熱炉・点火炉あるいは脱硫装置の白 煙防止用再熱炉なぞに利用するもので一部実用されて いる。比較的に直接利用しやすい温度領域の排熱(300 $\sim 350^{\circ} \mathrm{C}$ ) $4,000 \mathrm{Nm}^{3} / \mathrm{min}$ を回收し $80 \mathrm{Nm}^{3} / \mathrm{min}$ の Cガス節約の例なども報告されている。この熱空気は 現状一貫製鉄所の排熱としては比較的容易に大量の熱 回収可能領域にあるだけル，エネルギーバランスの条 件とのかね合いはあるが，蒸気あるいは電力としての 回収が試みられている。

コークス炉で製造される赤熱コークスを従来の湿式 消火から乾式消火（CDQ）にかえ不活性 ガスからの 熱回収として弥気を得る方式も昭和51年秋から世界最 大規模のものが稼動している。図 6 はその概念図であ る。コークス $\mathrm{t}$ あたり 350～500kg の蒸気を得ること ができ，一貫製鉄所の一般用蒸気をまかない切れるほ どの能力がある。しかし，既設設備では初期投資が莫 大なことと，製鉄所全体の蒸気バランスと関連したエ ネルギーバランス運用が問題となるので，未だ全般に 普及する技術としては認知されていない。環境問題を 含め立地条件などによって経済評価が大きく異なるの 
で技術的に設備上の問題はないが，将来の一貫製鉄所 エネルギー運用上の経済評価に委致るべき課題が残さ 孔ている。

以上が製鉄部門の 省エネルギー 対策の 数例である が，熱風炉の排熱回収や排煙脱硫脱硝装置の省エネル ギーなども活発に進められている。またこの部門では 送風機乞の他大容量の電動機に対する省電力対策も重 要な項目にあげられている。

\section{2 .2 製鋼・分塊部門}

製鋼工程でのエネルギー消費は総使用エネルギー量 の約 $2.3 \%$ であり非常に少ないようにみられる。しか し，現実には，熔鉄の潜顕熱や屑鉄の製造エネルギー が統計上カウントされないので実際には約 4 倍以上の エネルギーが投入されていることは注意を要する。し か子純酸素製鋼過程での高温発生や，造塊過程が古く から一貫製鉄所の高温職場の代表であったことなどは 広く知られている。

省エネルギーを歴史的にみるならば，平炉製鋼に代 る転炉製鋼，分塊圧延に代わる連続鋳造など製鋼法自 体のプロセス革命が結果として一貫製鉄所省エネルギ 一に大きく寄与している。製鋼工程での粗鋼 $\mathrm{t}$ あたり エネルギーは過去 15 年間で約 35\% 減を達成してい る。

この分野での省エネルギー対策の重点はプロセス自 体の品質歩留り向上対策と表裏一体をなしていると同 時に，素材の熱間移送に和汸る時間短縮，換言すれば 移送中の熱損失防止が課題で岁る。また, 最近は反応 によって排出されるェネルギーの回収も手近か尔対策 として採りあげられている。

連続鋳造 (C.C) プロセスは, 粗鋼 $\mathrm{t}$ 西たり約 20 万 $\mathrm{kcal}$ の省エネルギー効果があるといわれ，各製鉄所 之も適用品種の拡大に全力そ注いでいる。図 7 は連続 鋳造比率の推移を示したもので逐年その比率は高くな っている。一貫製鉄所の公称 800 万t 粗鋼生産をすべ て連続鋳造で処理している実例もある。

転炉から出鋼した熔鋼は，鋳型で造塊され型抜き後 均熱炉装入される。トラックタイム（型技きから均 熱炉装入までの時間）を短絔して移送工程での熱損失 を避けると同時に，鋼塊内部の未凝固部の凝縮熱を最 大限に利用する均熱炉ヒートパターンの改善も実用化 されている。傾斜加熱法, 階段加熱法, 逆 L 型加熱法 そいわれるるので図 8 はその概念の一例である。従来 法の約 $1 / 4$ 程度のエネルギー消費となり，今や各製鉄 所での新記録競争の観があり，月間実績值として鋼塊 $\mathrm{t}$ 西たり 4 万 $\mathrm{kcal}$ 弱の警異的な数值すら得られてい

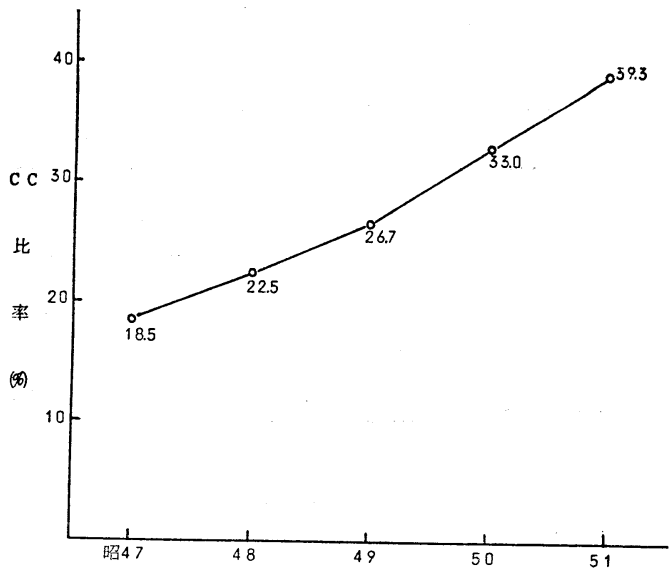

図 7 連続鋳造 (C.C) 比率の推移

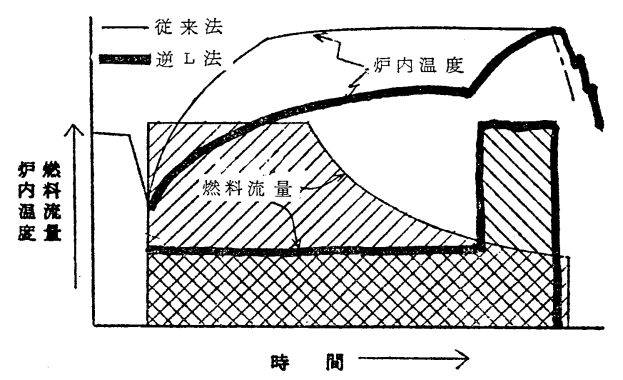

図 8 均熱炉逆 $\mathrm{L}$ 型加熱パターン

る。さらに，均熱炉の断熱強化などにより熱効率の向 上を目指している。

また，分塊圧延後のスラブを搬送する過程で，放散 熱を回収するスラブクーリングボイラーも一部で実用 されているが，製鉄所の条件によって経済性が異なる こと，熱間検查技術の向上と相俟って後にのべる直送 圧延などに移行する方向になりつつ峁ることなどか ら，設置例は少ない。

この分野での省エネルギー対策として見逃すことの できないるのに，転炉ガス（LD ガス）回収の強化が あげられる。従来から，燃焼型として蒝気回収方式か ら，非燃焼型としてのガス回収に移ってきたが，図 9 に示すような併用型も試みられている。図10はガス回 収型転炉の LD ガス回収率の推移である。ガス分析 と計装制御技術の 向上により $100 \mathrm{Nm}^{3} / \mathrm{t}$ の実績（月 間値）をあげている例もある。現在一貫製鉄所での貴 重なガス燃料として評価されている。

\subsection{3 圧延部門}

压延部門以各一貫製鉄所によって製造品種構成も異 なり，画一的には論じられないが，一貫製鉄所総使用 


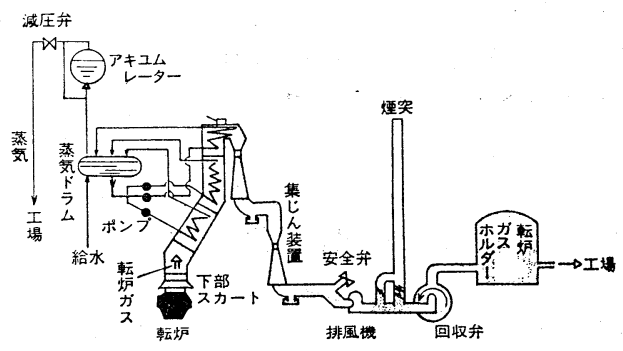

図 9 転炉排熱回収概念図

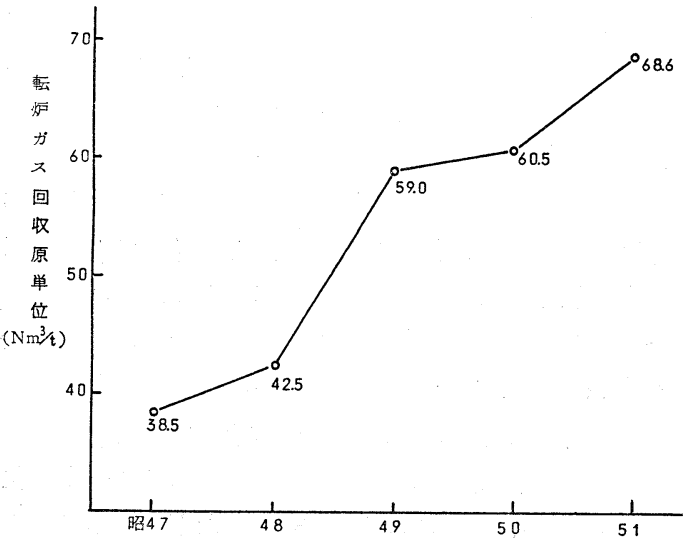

図 10 転炉ガス 回收原単位の推移 (2000kcal/ $\mathrm{Nm}^{3}$ 換算）ガス回収転炉の実績

エネルギー量の約 $8.5 \%$ を占め，らち加熱用燃料が $60 \%$ 加工用電力が $40 \%$ である。この分野では消費 エネルギーの絶対量に対して, 設備基数の多いことも 特色のひとつであり，省エネルギー対策は，きめ細か い具体策の積みあげの集大成といえるようである。現 在まで実施されている主な対策については表 2 亿示し た。

この分野では，燃焼や伝熱の基礎的熱解析の成果が 制御技術の進歩と結びついている。また， $\mathrm{NO}_{x}$ 対策 などを中心とした燃燒設備の改善も環境改善型省エネ ルギー技術として定着していることる特色といえる。 いずれにせよ，これらの技術は図11亿示す各加熱炉 然料原単位のように着実な成果をあげている。乙か も，現実の隇産下での実績であることを併せて考学る ならば，量産型から今や原点に立ら帰った姿での省エ ネルギー効果として高く評価できよう。

図12亿概念を示した直接圧延は分塊圧延後加熱炉工 程を省略するものであり，熱片装入は $300 \sim 1,000^{\circ} \mathrm{C}$ の素材を加熱炉に装入し加熱用然料の節減を図るもの である。この技術は優れた品質管理が前提条件となっ
表 2 圧延部門省エネルギー対策例

\begin{tabular}{ll}
\hline \multicolumn{1}{c}{ 熱間圧 延 } & \multicolumn{1}{c}{ 冷間 圧 延 } \\
\hline 直送圧延 & 炉運用の見直し \\
熱片装入 & 炉体断熱の強化 \\
抽出温度の低減 & 直火型炉の採用 \\
排ガス中 $\mathrm{O}_{2}$ 管理 & 空気予熱器の設置 \\
炉長延長 & 炉圧制御の改善 \\
噴流予熱法 & 蒸気使用の適正化 \\
スキッド二重断熱 & 連続焼鈍法 \\
ヒートパターンの適正化 & \\
排熱蒸気回収設置 & \\
電力使用の適正化 & \\
\hline
\end{tabular}

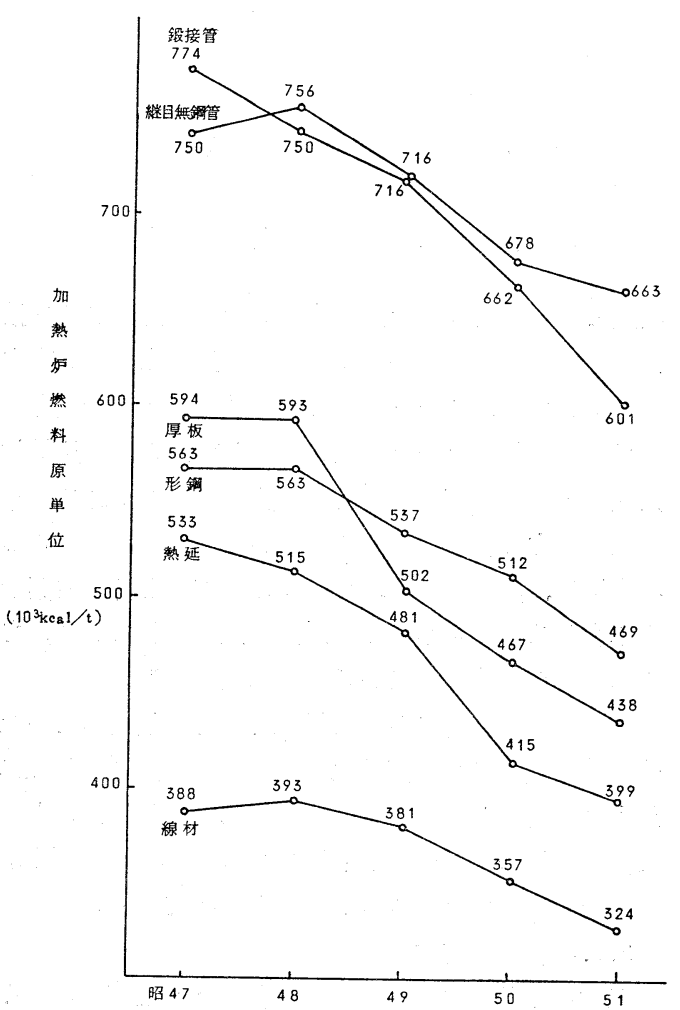

図 11 熱間压延加熱㶰燃料原単位推移

て特り，蓺間検査，熱間疵取り技術の向上ならびにそ れ以前の鋼塊そのものの品質向上があってはじめて達 成できるものである。直送圧延では加熱鋼材 $\mathrm{t}$ あたり 25 30万kcal，熱片装入は温度条件飞もよるが，5～ 20 万 kcal の省エネルギーが可能である。

加熱炉に特祇る省エネルギー対策のひとつに炉長を 延長し，対流伝熱を有效隹効かす方法があるが，一部 で行まわれている噴流予熱は排ガスを約 $70 \mathrm{~m} / \mathrm{sec} の$ 


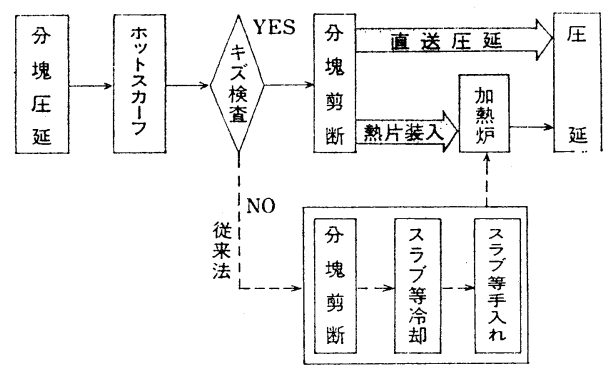

図 12 直送圧延，熱片装入概念図

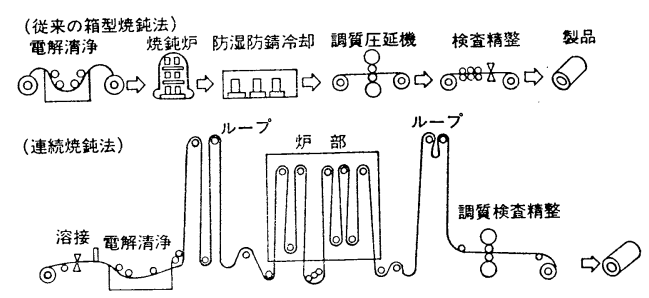

図 13 冷延連続焼鈍法概念図

高速で鋼材に吹きつけ，対流伝熱効果を上昇させる技 術開発であり，今後さらに改善され実用化される方向 にある。また, スキッドの二重断熱や炉体の断熱も, 軽量の断熱材の開発之施工方法の改善により, 比較的 効果的省エネルギー対策として見直されつつある。

圧延電力の合理的な使用については, 加熱炉からの 抽出温度, 愻材の型状, ロールの改善など各種要素を 組み合わせた省エネルギー対策が進められており，さ らに効果が期待されているのが現状である。

因13は冷延工場に祘いて従来それぞれ独立していた 焼鈍〜調質ラインを連続化した例である。この処理に 約 1 週間を要していたものに対し数分で仕上げるもの で, 生産性の 向上と結果的に約 10 15万kcal（成品 tあたり）の省エネルギー効果をあげている。

\section{2 .4 その他部門}

動力その他部門のエネルギー消費は総使用エネルギ 一量の約 14\% であるが，これらは共通のエネルギー として電力, 蒸気などの形で各生産工程に給付される ものである。

この部門はかつては補助部門として位置づけされ， 生産に支障なしにェネルギーの配分をつかさどるるの とされていたが，現状ではその機能が著しく変化しつ つある。すなおち, 計算制御の発達はエネルギーの集 中制御を可能とし，環境対策を含めた一元管理はもと よりエエネルギー需給最適配分として生産コストを含
めた需給プログラムの運用が可能となったのである。 もちろん, 現段階ではトータルコストミニマムに結び ついたエネルギーセンターの機能が $100 \%$ 達成され ているわけではない。しかし，現実にその方向に向け て改善されつつあることは疑う余地のない事実であ る。概念論としてでなく，具体的にこのような方向に 走り出したことは，一貫製鉄所に和汓るエネルギーの 重要性がより認識される段階に到達したことを物語っ ているとい光よう。

\section{4. むす び}

銑鋼一貫製鉄所に和ける省エネルギーの現況をのべ たが，不況滅産下での合理化の一環として努力してい ることは申すまでもない。そして，各論に例示したと 和りその成果は着実に結実しつつある。

現状では各社ともに中期省エネルギー目標を昭和 48 年度に対し約 $10 \%$ 節隇に置き，よい意味での企業間 競争を展開している。最初にのべたように, エネルギ 一価格の高騰に即効薬的に対処するのではなく, 製鉄 業全般の合理化の一環の中に省エネルギー対策が定着 しつつあることが，現状の位置づけといえよう。

しかも，現実には，たと壳ば高転炉スラグの資源化 と熱利用，中低温領域での排熱利用など，簡単にみ兄 て実用化にはな和幾多の関門の残されている課題も多 い。これらの解決には技術力の結集はもらろん必須条 件ではあるが，長期的にみれば第 2 のエネルギー危機 を回避する意味でも先行投資的技術開発も必要である と考兄られる。この機会を借りて，これらの情勢に適 応した。インセンティブが与兄られてさらに省エネル ギー対策が充実したものになるであるうことを強調し て招きたい。

最後に, 鉄鋼業界も今後の世界的エネルギー情勢に 打ち克つため，政策面では鉄鋼連盟のエネルギー対策 委員会を，技術面では鉄鋼協会の熱経済技術部会を中 心に各社間での情報交流や共同研究を行なっている。 また，現在，鉄鋼連盟が工業技術院から受託調査研究 を行なっている排熱利用トータルシステムプロジェク 卜子昭和 54 年度以降さらに輪を広げた形で発展的に他 研究機関に引き継ぐことになっている。

「エネルギーの使用の合理化関する法律」の成立 も間近いと聞している。今後とる, 広い視野からの 省エネルギー対策に積極的に取り組むことが，鉄鋼業 界の使命でもあることを痛感している。本稿に関して のご助言，ご叱正をいただければ幸甚である。

（本稿中の諸数值，眓は鉄鋼連盟資料から引用した） 


\title{
Outline of Energy Conservation in the Iron and Steel Industry
}

\author{
Yuzo SAGAWA \\ (Nippn Kokan K.K.)
}

SYNOPSIS :-For iron and steel industry in Japan, past five years were hard times, the sccalled "Energy crisis" and the following dipression drove this industry into retionalization of production.

The energy conservation is of vital importance to us. Now, we had luke to these techniques are fixing in the rationalization by degnees, at our iron and steel works. This paper reports [the energy consumption and some example of energy conservation techniques at various areas of iron steel industry in Japan, particularly of integrate workes. 